\title{
STRATEGI UMPAN BALIK MAHASISWA TERHADAP PERKULIAHAN MODEL PEMBELAJARAN IPA SD TAHUN AJARAN 2015/2016
}

\author{
Wiworo Retnadi Rias Hayu \\ Dosen Universitas Djuanda \\ E-mail:wiworo.iaz@gmail.com
}

\begin{abstract}
Abstrak
Evaluasi program perkuliahan Model Pembelajaran IPA SD dilakukan dengan tahapan evaluasi konteks, evaluasi input, evaluasi proses, evaluasi output dan evaluasi dampak. Semua data yang dikumpulkan menjadi kesatuan yang kompleks dari proses perencanaan, proses pelaksanaan dan proses penilaian. Tahap evaluasi konteks merupakan tahapan need assesment untuk mengetahui kebutuhan evaluasi. Evaluasi input merupakan evaluasi yang dilakukan dalam mengidentifikasi rencana perkuliahan semester (RPS) Model Pembelajaran IPA SD. Evaluasi proses mengidentifikasi proses perkuliahan Model Pembelajaran IPA SD. Evaluasi output merupakan evaluasi dari hasil penilaian, selain itu evaluasi ini dilengkapi dengan evaluasi dampak yang ditimbulkan setelah memperoleh perkuliahan Model Pembelajaran IPA SD. Laporan evaluasi program perkuliahan Model Pembelajaran IPA SD selanjutnya disampaikan kepada dosen pengampu mata kuliah, pihak yang berwenang, dan stakeholder yang berkepentingan dalam perkuliahan sehingga hasil evaluasi pembelajaran dapat menjadi rekomendasi perbaikan dan pengambilan keputusan.
\end{abstract}

Kata kunci: model pembelajaran IPA SD, evaluasi, dan program perkuliahan.

\section{PENDAHULUAN}

Menurut kamus bahasa Indonesia, Perkuliahan adalah mengikuti pelajaran di perguruan tinggi. Sedangkan menurut salah satu Admin Unipas, medefinisikan kegiatan perkuliahan adalah kegiatan akademik yang diselenggarakan oleh Fakultas dan Jurusan dapat berbentuk kuliah atau ceramah, seminar, diskusi. Jumlah waktu perkuliahan untuk setiap mata kuliah ditentukan berdasarkan beban studi sesuai dengan nilai kredit masing-masing mata kuliah. Jadi, perkuliahan merupakan kegiatan akademik yang dilakukan secara formal dan tersetruktur yang diikuti mahasiwa dalam mengikuti pelajaran di perguruan tinggi dan dosen sebagai pemberi materi. Salah satu mata kuliah yang akan dikaji yaitu Model Pembelajaran SD. Model Pembelajaran IPA SD merupakan salah satu mata kuliah di prodi PGSD Universitas Djuanda Bogor dengan Kode GSD342 dengan bobot 2 SKS.

Program perkuliahan Model Pembelajaran IPA SD merupakan perkuliahan yang meberikan pengetahuan tentang model-model yang cocok diterapkan pada mata pelajaran IPA di SD. Lima model pembelajaran yang dibahas merupakan rekomendasi kemendikbud yaitu model pembelajaran terpadu, model pembelajaran project based learning (PjBL), model pembelajaran problem based learning ( $P B L$ ), model pembelajaran inquiry dan model pembelajaran discovery. Selama perkuliahan satu semester akan membahas pengertian, karakteristik, jenis-jenis, assesment dan evaluasi, serta kelebihan dan kekurangan kelima model pembelajaran tersebut.

Program perkuliahan Model Pembelajaran IPA SD yang dipilih karena merupakan salah satu mata kuliah yang pertama kali diterapkan di Universitas Djuanda dengan metode blanded learning ( 40 $\%$ perkuliahan non tatap muka dan $60 \%$ perkuliahan tatap muka). Selain menggunakan teknologi yang lebih maju, perkuliahan blanded learning memfasilitasi mahasiswa dan dosen untuk tidak selalu bertemu di kelas. Kemudahan lainnya mahasiswa dapat mengakses materi perkuliahan dimanapun berada, dan tidak terbatas waktu dan tempat.

Program perkuliahan ini perlu adanya monitoring dan evaluasi supaya dapat memperbaiki program perkuliahan yang akan datang. Program yang menggunakan metode baru ini, perlu adanya tuntunan dan arahan lebih lanjut berdasarkan data di lapangan mengenai perencanaan, proses dan 
penilaiannya. Selain itu, menjadi rekomendasi untuk perbaikan dan perbenahan program perkuliahan tahun-tahun berikutnya. Hal tersebut dilakukan untuk meningkatkan kualitas dan mutu dari perkuliahan yang dilakukan.

Program perkuliahan Model Pembelajaran IPA SD bertujuan menghasilkan mahasiswa yang memiliki kompetensi pedagogik, kepribadian, sosial dan profesional berlandaskan pengetahuan dan pemahaman tentang bimbingan dan konseling yang menyatu dalam tauhid; mengetahui dan memahami ranah model pembelajaran IPA SD yang berkaitan erat dengan tauhid untuk pelayanan di sekolah dasar; memahami peranan guru dalam mencerdasakan anak bangsa yang menyatu dalam tauhid; memahami masalah-masalah dan cara mengatasinya untuk mencapai pendidikan yang optimal dan mampu menjadi konselor yang baik dalam kemajuan pendidikan anak sekolah dasar.

Struktur program perkuliahan Model Pembelajaran IPA SD dilakukan dalam satu semester dengan enam belas kali (16X) pertemuan. Setiap pertemuan dilakukan selama $2 \times 50$ menit. Materi kuliah dilakukan sebanyak empat belas kali (14X) dan dua kali penilaian (UTS dan UAS). Dosen meberikan kuliah melalui tatap muka dan melalui Learning Management System (LMS) yang sudah disediakan. Materi-materi dan tugas-tugas perkuliahan diunggah pada LMS yang sudah disediakan. Mahasiswa yang mengikuti perkuliahan hanya mahasiswa yang didaftarkan dalam perkuliahan tersebut dengan memiliki acount di LMS dengan username dan password masing-masing. Kegiatan diskusi bisa dilakukan dengan tatap muka di kelas maupun dalam forum diskusi yang disediakan dalam LMS.

Rasionalisasi program yang dilakukan sesuai dengan Rancangan Perkuliahan Semester (RPS). Program dapat berjalan dengan bantuan berbagai pihak, salah satunya tim pengembang LMS dan asisten pelaksanaan perkuliahan untuk menyediakan sarana serta prasarana yang digunakan dalam perkuliahan. Perkuliahan yang dilakukan walaupun non tatap muka menganjurkan mahasiswa untuk berkumpul dalam satu kelas untuk mempermudah koneksi dan pembelajaran.

Indikator keberhasilan program sesuai dengan indikator capain KKNI level 6 yang meliputi sikap, pengetahuan dan keterampilan umum maupun khusus. Indikator capaian pembelajaran pada aspek sikap meliputi mahasiswa mampu menunjukkan dalam perbuatan sikap religius dan bertaqwa kepada Tuhan yang Maha Esa; mampu menjalankan tugas dengan landasan agama, moral dan etika yang baik; mampu menunjukkan sikap bangga dan bertanggung jawab pada negara dan bangsa; mampu bertanggungjawab dengan kewajibanya yang diberikan secara mandiri. Indikator capain pembelajaran pada aspek pengetahuan meliputi mampu menerapkan konsep IPA dalam pembelajaran dan mampu menguasai semua model pembelajaran IPA yang sesuai diterapkan di SD. Indikator capain pembelajaran pada aspek keterampilan umum meliputi mahasiswa mampu pemikiran logis, kritis, sistematis, dan inovatif dalam konteks pengembangan atau implementasi model pembelajaran di SD. Indikator capain pembelajaran pada aspek keterampilan khusus meliputi mahasiswa mampu menerpakan konsep IPA dalam pembelajaran IPA dan mampu menganalisis, merekontruksi dan memodifikasi semua model pembelajaran IPA yang sesuai diterapkan di SD.

\section{METODE/EKSPERIMEN}

Desain evaluasi program yang digunakan dalam evaluasi program perkuliahan Model Pembelajaran IPA SD yaitu CIPP (Context, Input, Process, Product) dari Stufflebeam (Wortlen \& Sanders, 1997: 78). Model CIPP ini akan digunakan untuk mengevaluasi program tahapan untuk memulai dengan evaluasi konteks, evaluasi input sebagai tahap awal perencanaan perkuliahan yang sudah disusun, evaluasi proses pada saat perkuliahan Model Pembelajaran IPA SD dilakukan, evaluasi produk merupakan keluaran pada akhir perkuliahan berupa nilai akhir, selain itu evaluasi dampak setelah melaksanakan program tersebut.

Tahap awal evaluasi ini yaitu evaluasi konteks yang merupakan tahahapan need assesment. Tahap mengetahui kebutuhan diadakanya evaluasi program perkuliahan Model Pembelajaran IPA SD. Sasaran utama yang diidentifikasi adalah masalah-masalah yang dihadapi mahasiswa dalam mengikuti 
perkuliahan dan permasalahan-permasalahan yang dihadapi Dosen dalam memberikan perkuliahan. Permasalahan yang muncul dapat diidentifikasi mulai dari sarana-prasanan perkuliahan, bahan ajar yang dikembangkan, metode perkuliahan yang dilkukan, dan penilaian yang dilakukan.Berdasarkan kegiatan evaluasi kontek yang dilakukan dapat disimpulkan bahwa permasalahan berasal dari kebutuhan mahasiswa dan kewajiaban Dosen untuk memberikan perkuliahan, aspek penting yaitu adanya kesepakatan bersama dalam perkuliahan yang akan dilakukan.

Tahap kedua eavaluasi program ini yaitu tahap evaluasi input. Evaluasi input merupakan evaluasi yang dilakukan dalam mengidentifikasi rencana perkuliahan semester (RPS) Model Pembelajaran IPA SD. Melalui tahapan ini, disimpulkan bahwa RPS yang digunakan merupakan RPS yang bermutu dilihat dari standar yang sudah ada dan mengikuti capaian pembelajaran PGSD. Materi dan metode perkuliahan yang dilakukan sudah cocok dengan model pengajaran blanded learning atau belum.

Tahap ketiga evaluasi proses yang menjadi kegiatan inti yang memerlukan kejelian dan ketepatan dalam mengidentifikasi proses perkuliahan Model Pembelajaran IPA SD. Proses perkuliahan sudah dijalankan secara efektif, sesuai dengan RPS yang disusun dan sudahkan mencapai tujuan perkuliahan yang dilakukan. Temuan-temuan pada evaluasi proses dapat disampaikan kepada stakeholder dan pihak-pihak yang berkepentingan.

Tahap terakir evaluasi output dalam hal ini evaluasi dari hasil penilaian, selain itu evaluasi ini dilengkapi dengan evaluasi dampak yang ditimbulkan setelah memperoleh perkuliahan Model Pembelajaran IPA SD. Indikator-indikator keberhasil program perkuliahan yang dilakukan merupakan ranah penting untuk menjadi panduan dalam mengidentifikasi hasil penilaian dan dampak yang ditimbulkan. Evaluasi dampak berkaitan dengan apa sumbang pemikiran yang dihasilkan mahasiswa setelah memperoleh perkuliahan Model Pembelajaran IPA SD.

Data merupakan komponen kunci dalam evaluasi ini karena akan memberikan banyak informasi yang dibutuhkan. Data yang terkumpul dapat berupa data kuantitatif maupun kualitatif. Instumen yang digunakan pun harus beragam dan komplek supaya data yang dihasilkan holistik dan lengkap. Kegiatan yang dilakukan dengan menyebarkan angket dan wawancara ke beberapa mahasiswa selain itu data perencanaan serta penilaian dapat dilihat dari hasil analisis dokumen berupa RPS, tugas-tugas, LMS, forum diskusi di LMS, Penilaian UTS dan UAS. Evaluasi ini tidak hanya mahasiswa sebagai subjek tetapi juga mahasiswa.

Evaluasi terhadap dosen dilakukan oleh mahasiswa dengan mengisi kuisioner yang telah diberikan Lembaga Penjaminan Mutu (LPM) yang mencakup empat hal penting dalam pelaksanaan belajar mengajar yaitu materi perkuliahan, penyampaian materi kuliah, pengelolaan kelas dan evaluasi pengajaran.

\section{Tabel 1. Bidang Aspek PBM}

\begin{tabular}{|c|c|c|}
\hline No & Bidang Aspek & Aspek yang dinilai \\
\hline \multirow[t]{3}{*}{1.} & \multirow[t]{3}{*}{ Materi Perkuliahan } & $\begin{array}{l}\text { Penyampaian RPS, sistem evaluasi dan buku referensi pada pertemuan } \\
\text { pertama. }\end{array}$ \\
\hline & & Bahan ajar diberikan Dosen pada perkuliahan yang dilakukan. \\
\hline & & $\begin{array}{l}\text { Tugas yang diberikan dosen selama perkuliahan relevan dengan materi } \\
\text { kuliah. }\end{array}$ \\
\hline \multirow[t]{4}{*}{2.} & \multirow{4}{*}{$\begin{array}{l}\text { Penyampaian } \\
\text { Materi Perkuliahan }\end{array}$} & Materi kuliah yang disampaikan dosen sesuai dengan RPS \\
\hline & & Keterkaitan antar materi kuliah yang diberikan selama perkuliahan \\
\hline & & Tanggapan dosen atas pertanyaan yang diberikan mahasiswa \\
\hline & & $\begin{array}{l}\text { Materi kuliah yang disampaikan dosen dalam memotivasi mahasiswa untuk } \\
\text { belajar. }\end{array}$ \\
\hline \multirow[t]{3}{*}{3.} & \multirow[t]{3}{*}{ Pengelolaan Kelas } & Penyampaian pesan-pesan moral keagamaan dari dosen. \\
\hline & & Kesesuian antara pelaksanaan dengan jadwal perkuliahan. \\
\hline & & Media yang digunakan dosen dalam melaksanakan pembelajaran. \\
\hline \multirow[t]{3}{*}{4.} & \multirow{3}{*}{$\begin{array}{l}\text { Evaluasi } \\
\text { Pengajaran }\end{array}$} & Sikap dosen dalam menghadapi kesulitan dan kritikan mahasiswa. \\
\hline & & Keseuaian materi ujian (UTS/UAS) dengan materi yang diajarkan. \\
\hline & & Pengembalian berkas hasil ujian, kuis dan tugas kepada mahasiswa. \\
\hline
\end{tabular}

(diadopsi Yusdiarti, 2017:2) 
Indikator tingkat kepuasan dilihat dari data kuantitatif yang diperoleh dari hasil rata-rata penilaian mahasiswa. Nilai $>4$ menunjukkan bahwa penilian dalam kategori "baik", sedangkan nilai $<4$ menunjukkan bahwa penilaian dalam kategori kurang sebaiknya dilakukan perbaikan. Selain data dari mahasiswa, dosen, juga data yang diperoleh dari LMS, tugas-tugas serta forum diskusi. Data yang terkumpul dari tahapan evaluasi konteks, input, proses, output dan dampak menjadi data utama yang dilaporkan.

Tabel 2. Struktur Data dan Instrumen Evaluasi Program Perkuliahan Model Pembelajaran IPA SD

\begin{tabular}{|c|c|c|c|c|}
\hline No & Aspek & Fokus & Metode & Instrumen \\
\hline 1. & $\begin{array}{l}\text { Evaluasi } \\
\text { Konteks }\end{array}$ & $\begin{array}{l}\text { Masalah-masalah yang } \\
\text { dihadapi mahasiswa dan Dosen } \\
\text { seperti sarana-prasanan } \\
\text { perkuliahan, bahan ajar yang } \\
\text { dikembangkan, metode } \\
\text { perkuliahan yang dilkukan, dan } \\
\text { penilaian yang dilakukan }\end{array}$ & $\begin{array}{l}\text { Analisis dokumen, } \\
\text { interview,observasi. }\end{array}$ & $\begin{array}{l}\text { Pedoman } \\
\text { interview, } \\
\text { kuisioner, } \\
\text { pedoman } \\
\text { observasi dan } \\
\text { pedoman } \\
\text { analisis } \\
\text { dokumen. }\end{array}$ \\
\hline 2. & $\begin{array}{l}\text { Evaluasi } \\
\text { Input }\end{array}$ & $\begin{array}{l}\text { Mengidentifikasi } \\
\text { program perkuliahan (RPS) } \\
\text { Model Pembelajaran IPA SD }\end{array}$ & Analisis dokumen & $\begin{array}{l}\text { Pedoman } \\
\text { analisis } \\
\text { dokumen }\end{array}$ \\
\hline 3. & $\begin{array}{l}\text { Evaluasi } \\
\text { Proses }\end{array}$ & $\begin{array}{l}\text { Kegiatan perkuliahan sudah } \\
\text { dijalankan secara efektif, sesuai } \\
\text { dengan RPS yang disusun dan } \\
\text { sudahkah mencapai tujuan } \\
\text { perkuliahan yang dilakukan. }\end{array}$ & Observasi & $\begin{array}{l}\text { Lembar } \\
\text { Observasi }\end{array}$ \\
\hline 4. & $\begin{array}{l}\text { Evaluasi } \\
\text { Output }\end{array}$ & $\begin{array}{l}\text { Analisis dokumen berupa RPS, } \\
\text { tugas-tugas, LMS, forum } \\
\text { diskusi di LMS, Penilaian UTS } \\
\text { dan UAS. }\end{array}$ & Analisis Dokumen & $\begin{array}{l}\text { Pedoman } \\
\text { analisis } \\
\text { dokumen }\end{array}$ \\
\hline 5. & $\begin{array}{l}\text { Evaluasi } \\
\text { Dampak }\end{array}$ & \begin{tabular}{lrr} 
Evaluasi & dampak & berkaitan \\
dengan apa & sumbang \\
pemikiran yang & dihasilkan \\
mahasiswa & setelah \\
memperoleh perkuliahan Model \\
\multicolumn{2}{l}{ Pembelajaran IPA SD. }
\end{tabular} & Wawancara & $\begin{array}{l}\text { Lembar } \\
\text { wawancara }\end{array}$ \\
\hline
\end{tabular}

(Adaptasi dari Firman, H. \& Kuniawati, I. 2007 \& Firman, H. 2008)

(1)

\section{HASIL DAN PEMBAHASAN}

Data yang diperoleh berupa data kuantitatif maupun kualitatif. Hal tersebut perlu adanya analisis data hasil sesuai dengan jenis data yang dikumpulkan. Data kualitatif dianalisis melalui metode deskreftif kualitatif sedangankan data kuantitatif bisa dianalisis menggunakan statistik sederhana dan deskreftif kuantitatif. Data tahapan evaluasi konteks, evaluasi input, evaluasi proses, evaluasi output dan evaluasi dampak dianalisis sesuai dengan jenis data masing-masing. Data dari mahasiswa, dosen, tugas-tugas dan LMS juga menjadi data pelengkap untuk menyusun data yang lebih kompleks.

Penyusunan laporan berdasarkan hasil analisis data yang diperoleh. Setiap tahap dianalisis dan dilaporkan sesuai dengan data yang ditemukan. Hasil laporan yang disusun mengambarkan semua proses program yang dilakukan dalam satu semester. Laporan evaluasi program perkuliahan Model Pembelajaran IPA SD selanjutnya disampaikan kepada dosen pengampu mata kuliah, pihak yang berwenang, dan stakeholder yang berkepentingan dalam perkuliahan sehingga hasil evaluasi pembelajaran dapat menjadi rekomendasi perbaikan dan pengambilan keputusan. 


\section{PENUTUP}

Evaluasi program perkuliahan Model Pembelajaran IPA SD dilakukan dengan tahapan evaluasi konteks, evaluasi input, evaluasi proses, evaluasi output dan evaluasi dampak. Semua data yang dikumpulkan menjadi kesatuan yang kompleks dari proses perencanaan, proses pelaksanaan dan proses penilaian. Program perkuliahan Model Pembelajaran IPA SD merupakan perkuliahan yang salah satunya mengunakan metode baru yaitu blanded learning. Hal tersebut merupakan program perkuliahan uji coba yang akan menentukan metode blanded learning terus diterapkan ataupun dihentikan. Oleh sebab itu, perlu adanya evaluasi program perkuliahan ini yang nantinya akan memberikan banyak masukan atau perbaikan jika program dilanjutkan ataupun dihentikan karena kurang efektif dan menemui banyak kendala. Setiap program yang baru diterapkan pasti menemukan banyak kendala tetapi alangkah bijaksana jika kendala tersebut seterusnya diperbaiki dan menciptakan perkuliahan yang lebih baik. Setiap mata kuliah memiliki karakteristik yang berbeda-beda oleh karena itu diharapkan dalam mengadopsi ataupun menyikapi kegiatan evaluasi ini secara bijak dan penuh pertimbangan kegiatan yang dilakukan cocok ataupun kurang cocok.

\section{DAFTAR PUSTAKA}

Anonim. (2016). Perkuliahan. Diakses dari http://www.fisip-unipas.com pada Sabtu, 22 April 2017.

Anonim. (2017). Kamus Besar Bahasa Indonesia Online. Diakses dari Kbbi.web.id. pada Sabtu, 22 April 2017.

Firman, H. \& Kuniawati, I. (Eds). (2007). Monitoring \& Evaluasi Program Lesson Study: Lesson Learned dari JICA-SISTEMS. Bandung: FPMIPA Universitas Pendendidikan Indonesia.

Firman, H. (2008). Monitoring and Evaluation Strategy of Lesson Study Programme; Strategi Monitoring dan Evaluasi Program Lesson Study. Internasional Conference on Lesson Study. Faculty of Mathematics and Science Education Indonesia University of Education on July 31 - August 01 , 2008.

Fitzpatrick, J. L., Sanders, J. R., \& Worthen, B. R. (2012). Program evaluation: Alternatives, approaches, and practical guidelines ( $4^{\text {th }}$ ed.). Boston: Pearson Education Inc.

Stigler, J.W. \& Hiebert, J. (1999). The Teaching gap: Best Ideas from The World's Teacher for Improving Education in The Classroom. New York: The Free Press.

Worthen, B. R. \& Sanders, J. R. (1997). Educational Evaluation: An Alternative Approaches and Practical Guidance. White Plains (NY): Logman.

Yudisarti, A. (2017). Laporan Hasil Evaluasi PBM Semester Ganjil 2016/2017. Bogor: Lembaga Penjaminan Mutu Universitas Djuanda. 